\title{
Topographic characteristics of landslides induced by the 2015 Gorkha earthquake, Nepal
}

\author{
*Ching-Ying Tsou ${ }^{1}$, Daisuke Higaki ${ }^{1}$, Masahiro Chigira ${ }^{2}$, Hiroshi Yagi ${ }^{3}, V_{i s h u ~ D a n g o l}{ }^{4}$, Shanmukhesh Amatya $^{5}$, \\ Kazunori Hayashi ${ }^{6}$, and Hiroki Kato ${ }^{1}$ \\ ${ }^{I}$ Department of Agricultural and Environmental Engineering, Hirosaki University, Hirosaki, Aomori, Japan \\ ${ }^{2}$ Disaster Prevention Research Institute, Kyoto University, Uji, Kyoto, Japan \\ ${ }^{3}$ Department of Education, Art and Science, Yamagata University, Yamagata, Japan \\ ${ }^{4}$ Department of Geology, Tribhuvan University, Kathmandu, Nepal \\ ${ }^{5}$ Department of Water Induced Disaster Management, Ministry of Irrigation, Kathmandu, Nepal \\ ${ }^{6}$ Okuyama Boring Co., Ltd., Sendai, Miyagi, Japan \\ *Corresponding author: tsou.chingying@hirosaki-u.ac.jp
}

\begin{abstract}
The 2015 Gorkha earthquake and its aftershocks induced landslides in central Nepal. In this study, field surveys were conducted, and Google Earth satellite images were analysed for pre- and post-mainshock and aftershock scenarios to clarify the distribution of landslides. A total of 13,097 new landslides and 750 enlarged landslides were identified and mapped as polygon-based data over an area of $7.8 \times 103 \mathrm{~km}^{2}$ between the epicentres of the main shock and the largest aftershock at the mountainous southern margin of the High Himalayas. Shallow-disrupted landslides were the most common type of mass movement. The areas of individual landslides ranged from 10 to $3.2 \times 105 \mathrm{~m}^{2}$, covering a cumulative area of $5.4 \times 107 \mathrm{~m}^{2}$ or $0.7 \%$ of the study area. The landslide density was high in the Gorkha, Rasuwa, and Sindhupalchok districts, indicating that these areas suffered greater damage. Landslides occurred mainly on steep slopes $\left(>35^{\circ}\right)$ in V-shaped inner gorges, on geologically controlled steep slopes such as the scarp slopes (infacing slopes) of mountain ridges, and on terrace scarps. The results suggest that earthquake-induced landslides occur on slopes preconditioned by topographic and litho-structural factors. Based on our observations, recommendations for the mitigation of future landslide disasters are provided.
\end{abstract}

Keywords: Gorkha earthquake, Landslide, Mapping, Landslide data

Paper Received: 29 Jan 2018

Paper Accepted: 25 March 2018

\section{INTRODUCTION}

The Gorkha earthquake occurred in central Nepal at 11:56 am local time (7:05 UTC) on April 25, 2015 (USGS, 2015) and ruptured the Main Himalayan Thrust (Duputel et al., 2016). The earthquake had a magnitude of Mw 7.8 and was followed by hundreds of aftershocks, including a Mw 7.3 major aftershock on May 12, 2015 (USGS, 2015). The earthquake had no clear geomorphic expression or surface rupture (Angster et al., 2015), but the mainshock and aftershocks caused many landslides (Kargel et al., 2015). The landslides caused $>9000$ fatalities and damaged infrastructure (Kargel et al., 2015), making this the most devastating earthquake in Nepal since the 1934 Nepal-Bihar earthquake (Sapkota et al., 2016).

Several studies have interpreted the distribution of landslides associated with the Gorkha earthquake using field reconnaissance and satellite images, and analysed their controlling factors (Kargel et al., 2015; Martha et al., 2017; Roback et al., 2017; Tiwari et al., 2017). The landslides are mainly shallow-disrupted landslides and are distributed across the Lesser and Higher Himalayas (Roback et al., 2017), and developed in Proterozoic metamorphic units and intrusive complexes (Kargel et al., 2015). A high landslide density correlates with steep topography $\left(>30^{\circ}\right)$ and high peak ground acceleration during the earthquakes $(>0.6 \mathrm{~g})$ (Kargel et al., 2015).

Previous studies have provided digital maps of landslide distribution, but freely available landslide inventories are limited and are only available as GIS point data (Kargel et al., 2015) or polyline-based data (British Geological Survey, 2015). Furthermore, pre-existing and enlarged landslides have not been discriminated in the mapping (e.g., Tsou et al., 2017). In this paper, we develop two polygon-based inventories of landsides that were enlarged or newly induced by the 2015 Gorkha earthquake and its aftershocks. We report on and discuss the characteristics and distribution of the landslides and make recommendations for the mitigation of future landslide disasters. This paper presents some of the main results of the Japan-Nepal Urgent Collaborative Project, which focussed on the April 2015 Nepal earthquake as part of the J-Rapid Program of the Japan Science and Technology Agency (JST-PROJECT-15657342). 


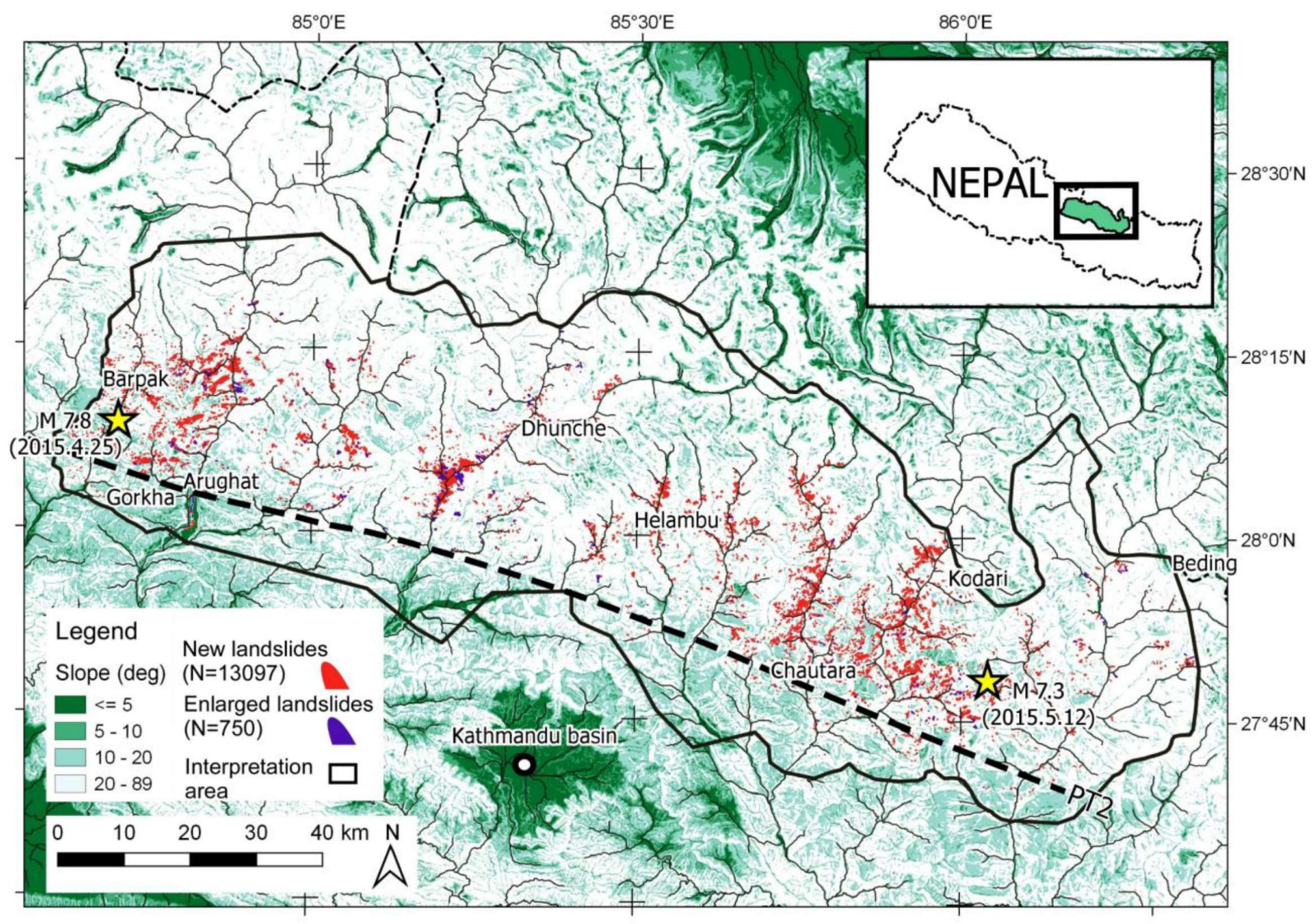

Fig. 1: Distribution of earthquake-induced landslides superimposed on a slope inclination map. The slope image is derived from a 30-m mesh ASTER DEM. The dashed line indicates the physiographic transition PT2 (Harvey et al., 2015). The stars indicate the epicentres of the main shock (Mw 7.8) and the largest aftershock (Mw 7.3) (USGS 2015).

\section{Study area}

The study area of $7.8 \times 10^{3} \mathrm{~km}^{2}$ is mountainous, at elevations from 360 to $7230 \mathrm{~m}$ (Fig. 1). The area covers six districts such as Gorkha, Rasuwa, Dhadin, Nuwakot, Sindhupalchouk, and Dolakha. The major rivers are the Daraundi Khola, Budhi Gandaki, Trishuli River, Sun Koshi, Bhote Koshi, and Tama Koshi, which all flow southwards. V-shaped fluvial gorges with steep hillslopes are distinct geomorphic features of these river catchments, with local increases in relief of $400 \mathrm{~m}$ over horizontal distances of $<1000 \mathrm{~m}$. Longitudinal profiles of these rivers show distinct knickpoints distributed to the north of a macroscale physiographic transition, referred to as physiographic transition 2 (PT2; Harvey et al., 2015). PT2 is located just south of the Main Central Thrust (MCT), marking the boundary between the Lesser and Higher Himalayas. The geology of the study area comprises high-grade metamorphic rocks such as quartzite, migmatite, and gneiss of the Higher Himalayan Crystallines, and phyllite, schist, carbonate, and amphibolite of the Lesser Himalayan strata (Shrestha and Shrestha, 1986).

\section{METHODS}

Landslides induced by the 2015 Gorkha earthquake and its aftershocks are interpreted from Google Earth images. The landslides were detected from images taken after the main shock and major aftershock, and before the rainy season (i.e., May 3, May 14, and May 25, 2015) and were compared with images taken in December 2014. The morphometric criteria used for landslide identification included the arcuate shape of a landslide scar, exposure of debris or bedrock in the scar, deposition of coarse debris downslope, and stronger surface reflectivity relative to the surrounding vegetation (Tiwari et al., 2017). Ice- and snow-covered areas on satellite images taken in May 2015 are not included because the landscape frequently changes due to snowfall, meaning that landslide detection is difficult. The landslides were mapped as polygons and subdivided into two datasets consisting of new and enlarged landslides. New landslides are those only recognised in the post-earthquake image, and enlarged landslides are those identified in a preearthquake image and cover a greater area in the post-earthquake images, and are mapped together with the pre-existing landslides. We defined the source, transition, and deposition areas within 
each landslide polygon. To complement the image analysis, field investigations were conducted in the Gorkha, Nuwakot, Rasuwa, and Sindhupalchouk districts.

\section{RESULTS AND DISCUSSION}

\section{Landslide characteristics}

A total of 13,097 new landslides and 750 enlarged landslides were identified (Fig. 1). Shallow-disrupted landslides are the predominant landslide type and are characterised by rock falls, debris slides, and rock (debris) avalanches. The highest landslide density was identified in the Gorkha, Nuwakot, and Sindhupalchouk districts. Landslide occurrence increased significantly to the north of PT2, where the terrain is steeper and receives a high mean annual precipitation, indicating that slopes destabilised by the Gorkha earthquake could be prone to further mass movements in the coming rainy seasons. The potential for debris flows to occur increases after an earthquake, as arose after the 1999 Chi-Chi earthquake in Taiwan (Lin et al., 2004) and the 2008 Wenchuan earthquake in China (Tang et al., 2016). Debris deposited on slopes or accumulated on valley floors and river beds may be mobilised as debris flows in the rainy season, and might continue to do so for years to come. The sediment load transferred downstream during a flood also increases along rivers with abundant earthquake-induced landslides in their catchment areas.

The individual landslides ranged from 10 to $3.2 \times 10^{5}$ $\mathrm{m}^{2}$ in area (Fig. 2), covering a cumulative area of $5.4 \times 10^{7} \mathrm{~m}^{2}$ or $0.7 \%$ of the study area. Our landslide inventories include landslides with areas $<10^{3} \mathrm{~m}^{2}$, which account for $29 \%$ and $7 \%$ of the number of new and enlarged landslides, respectively (Fig. 2 ). These smaller landslides can destroy buildings and roads, and can cause more damage than larger landslides.

Numerous landslides can be seen on satellite images to the northeast of Kathmandu and to the west of Kodari in the

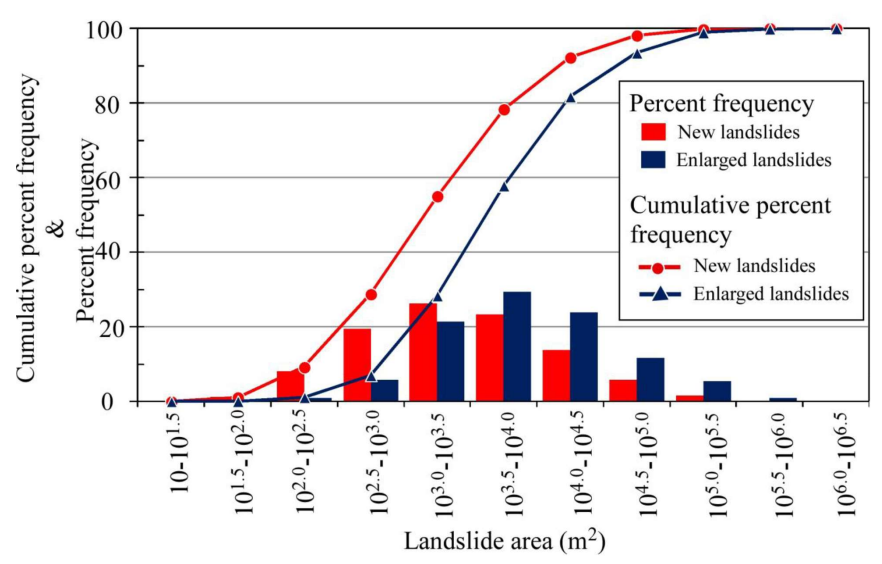

Fig. 2: Percent frequency and cumulative percent frequency of landslide number versus landslide area for new and enlarged landslides
Higher Himalayan Crystallines, outside our survey area. Those landslides occurred on very steep slopes and may have been controlled by joint systems within the crystalline rocks.

In comparison with landslides induced by the 2008 Wenchuan earthquake (Mw 7.9) (Chigira et al., 2010), the 2015 Gorkha earthquake induced more small-scale landslides (Fig. 3) with no comparable gigantic landslides (Fig. 3). This difference may be attributed to the Gorkha earthquake occurring in the dry season, with no heavy precipitation recorded at the time (Tsou et al. 2017). Antecedent rainfall can contribute to landslide formation by raising the groundwater level and increasing the pore water pressure (Chigira, 2014; Higaki et al., 2015). Even though gigantic landslides were not induced by the 2015 Gorkha earthquake, Collins and Jibson (2015) conducted helicopter reconnaissance following the event and observed slope deformation such as ground cracks on ridge tops, which could develop into landslides and threaten downslope settlements. The cracks were also observed near the steep toe slopes of landslides, so their retrogressive development must be monitored to evaluate the possibility of future catastrophic failure.

\section{Landslide distribution}

Fig. 4 shows the distribution of earthquake-induced landslides. Most landslides are concentrated on the steep slopes $\left(>35^{\circ}\right)$ of $\mathrm{V}$-shaped inner gorges, bounded by convex slope breaks. This is evident in the Trishuli River catchment (Fig. 5a and b), where the steep inner gorges of gneiss and sandstone or quartzite are loosened by gravitational forces (Tsou et al., 2017). Discontinuities such as stratification, joints, and fractures

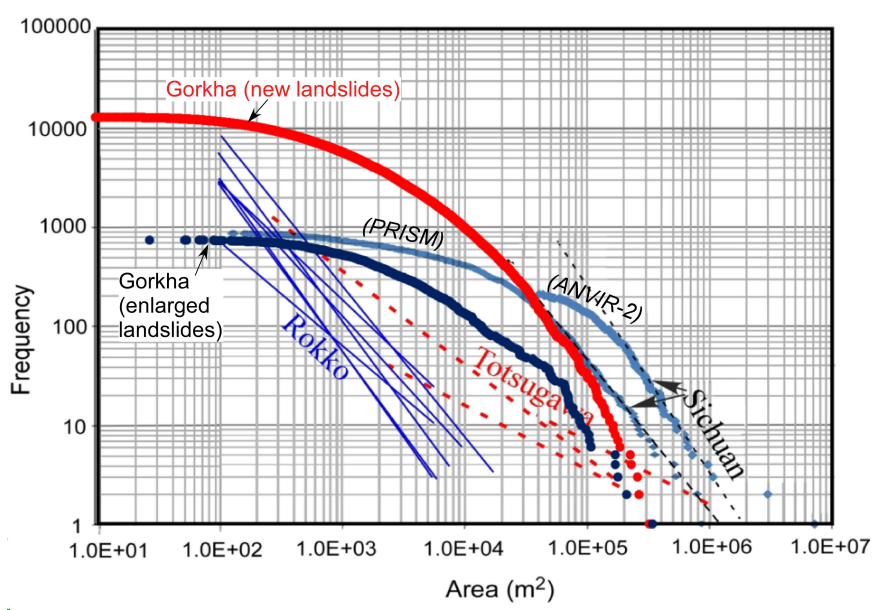

Fig. 3: Cumulative landslide frequency and landslide area. New and enlarged landslides of the Gorkha earthquake are added to a figure from Chigira et al. (2010). Sichuan data of the $\mathbf{2 0 0 8}$ Wenchuan earthquake are used for comparison with our landslide data. The Sichuan data are compiled by using PRISM images for the landslides northeast of Beichuan and AVNIR-2 images for larger investigated area (c.f. Chigira et al., 2010). 


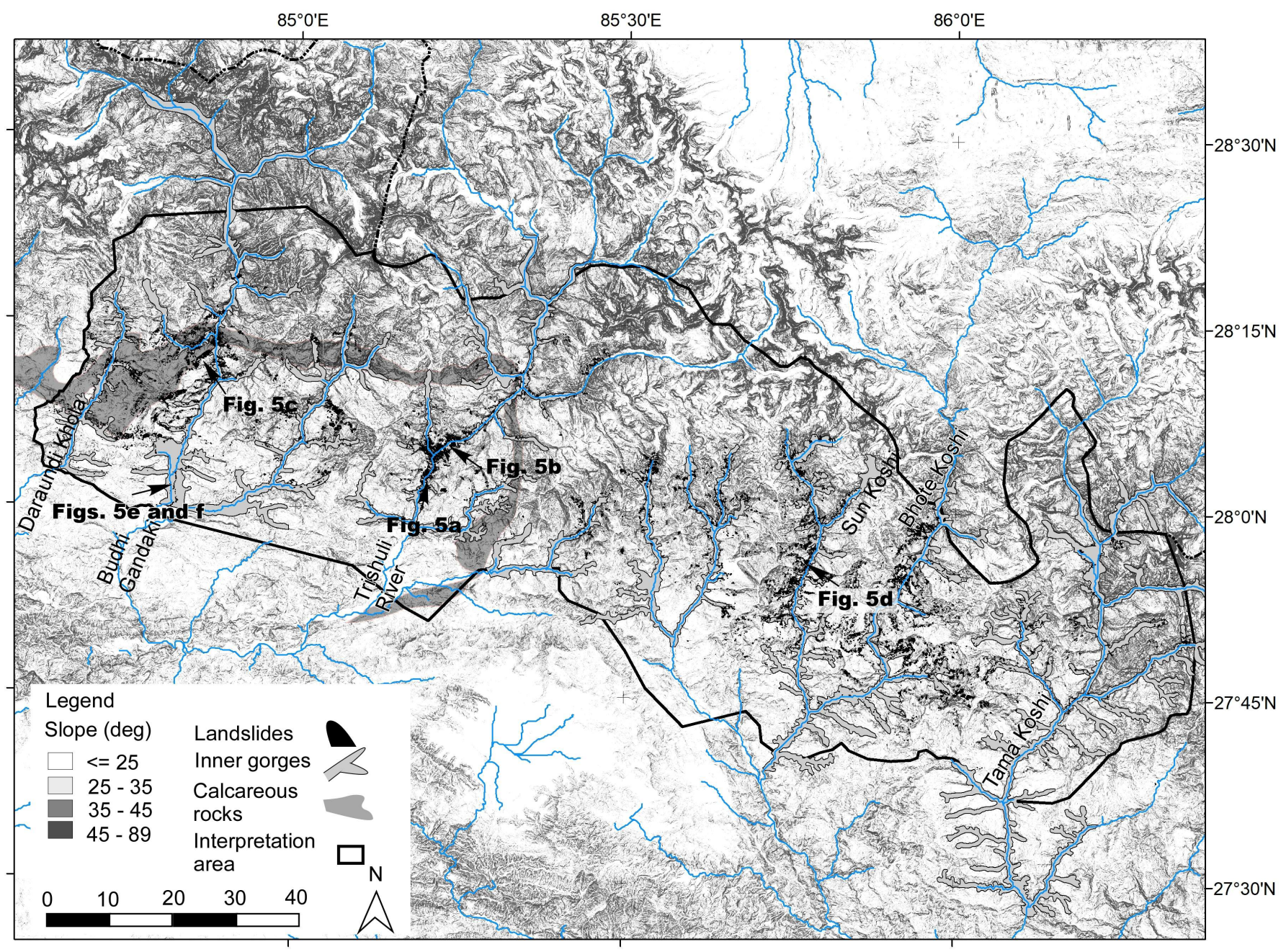

Fig. 4: Superimposed classified slope angles, earthquake-induced landslides, inner gorges, and calcareous rocks. Distribution of calcareous rocks is from (Shrestha and Shrestha, 1986). The classified slope image is derived from a 30$m$ mesh ASTER DEM. Scarp slopes are generally SW-facing with slope angles of $>35^{\circ}$. Arrows indicate the locations of the oblique views shown in Fig. 5.

are present in the rocks, and are favourable for the generation of earthquake-induced landslides (e.g. Tsou et al., 2017). The Sun Koshi and Bhote Koshi catchments also have many landslides on inner gorge slopes (Fig. 4).

Many steep scarp slopes (infacing slopes $>35^{\circ}$ ) along mountain ridges also failed in the Trishuli River, Bhote Koshi, Budhi Gandaki, and Daraundi Khola catchments. The scarp slopes are SW-facing, where the foliation dips into the slope and litho-structural control is mainly exerted by bedding and joints (Fig. 5c and d). Landslides are particularly common on scarp slopes comprising carbonate rocks in the Bhote Koshi and Budhi Gandaki catchments. Dissolution of calcareous rocks is observed along fractures, creating voids that reduce the mechanical strength and resilience of the strata to shaking. This characteristic was also observed in the 2005 Northern Pakistan earthquake (Sato et al., 2007) and the 2008 Wenchuan earthquake (Chigira et al., 2010).
Landslides on terrace scarps were also observed (Fig. 5 e and $\mathrm{f}$ ). Terrace deposits containing larger boulders failed and struck residential houses and destroyed roads, suggesting that terrace deposits are highly susceptible to earthquake shaking. This type of landslide was observed in Kodari and to the south of Arughat and Barpak. Lastly, large mass movements associated with deep-seated landslides were not induced by the earthquake, but their headscarps and steep toes were susceptible to shaking, and small debris slides formed because of the Gorka earthquake. Our results reveal that the majority of the earthquake-induced landslides are located on V-shaped inner gorge slopes, terrace scarps, and the steep scarp slopes of mountain ridges. Field observations confirm that shaking may be amplified in the convex parts of V-shaped inner gorges, terrace scarps, and crest slopes (Keefer, 1984; Wakai and Ugai, 2004).

Inner valleys are highly vulnerable to earthquake-induced landslides, and many hydropower stations and trunk roads were 

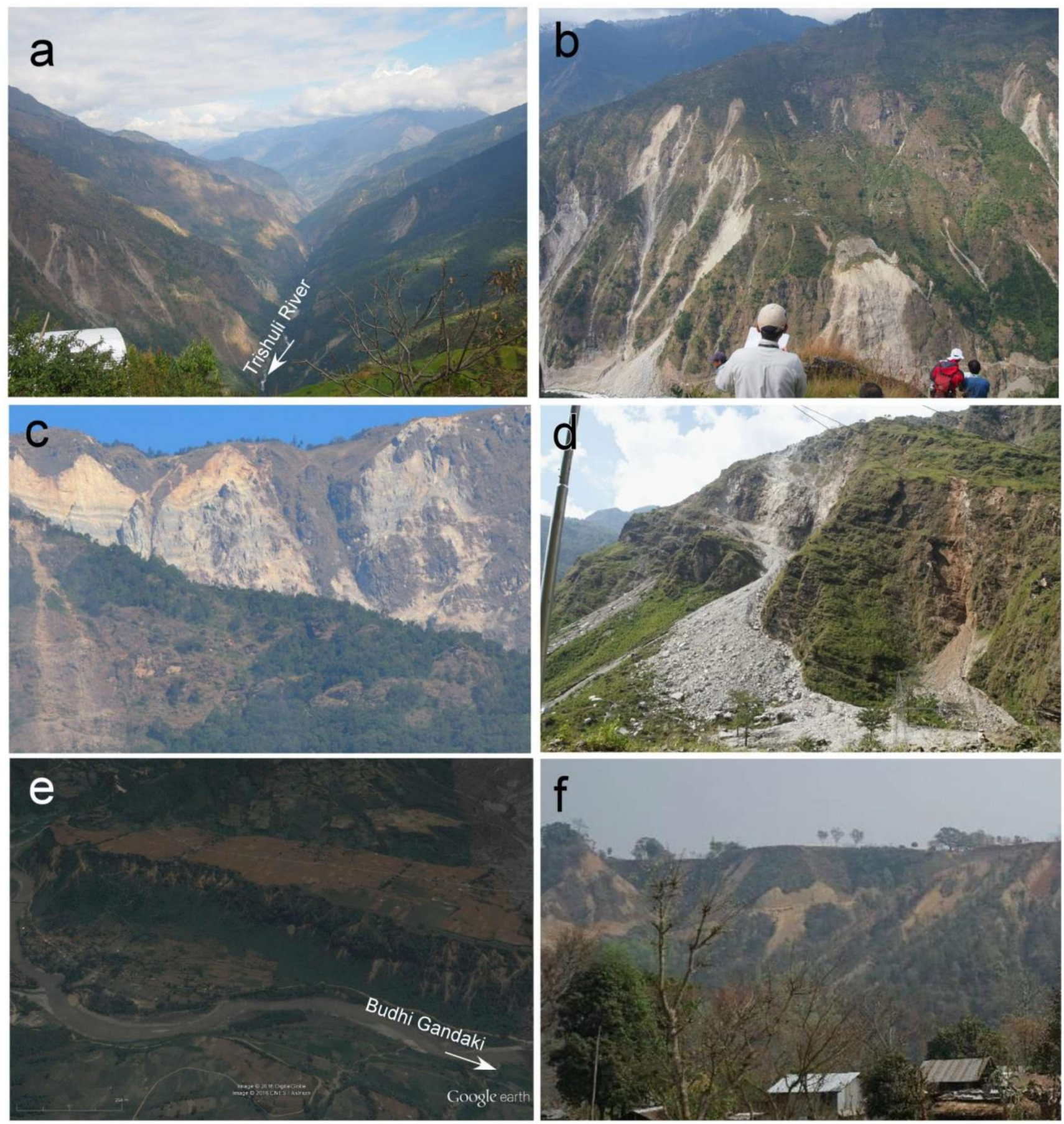

Fig. 5: Examples of landslides within V-shaped inner gorges (a and b), scarp slopes (c and d), and terrace scarps (e and f). A Google Earth image is used in (e).

heavily damaged by the 2015 landslides (Chiaro et al., 2015). The construction of underground hydropower stations could reduce the costs of maintaining penstocks, power houses, and access roads, and would provide a stable supply of electricity, although construction costs would be much higher. Important trunk roads would be better located on gentler slopes above the convex valley slope break; e.g., the Rasuwa Route (Pasang-Lhamu Road) passing through Dhunche, which is built in such a location, was scarcely damaged by the earthquake. In contrast, the Araniko Highway is located mainly along a river within inner valleys, and is at high risk of landslides during earthquakes, resulting in high levels of maintenance. 


\section{CONCLUSIONS}

This study presented the distribution of landslides induced by the Gorkha earthquake in 2015, in a mountainous area of $7.8 \times 10^{3} \mathrm{~km}^{2}$ between the epicentres of the main shock (Mw 7.8) and the largest aftershock (Mw 7.3). We mapped 13,847 earthquake-induced landslides, mainly shallow-disrupted landslides, which included 750 enlarged pre-existing landslides and 13,097 new landslides. The landslides often occurred on the steep slopes of V-shaped inner gorges, scarp slopes, and terrace scarps. The landslides on inner gorges and scarp slopes were associated mainly with fractured rock masses, whereas landslides on the terrace scarps occurred where large bounders failed from terrace deposits. Our findings suggest that these slopes are prone to earthquake-induced landslides and that geomorphological classification may mitigate future landslide disasters. Furthermore, attention needs to be paid to possible future disasters such as debris flows and retrogressive development of ground cracks. Gentler slopes above the convex valley slope break are suggested places for road construction.

\section{ACKNOWLEDGEMENTS}

This study presents some of the main results of the Japan-Nepal Urgent Collaborative Projects regarding the April 2015 Nepal earthquake as part of the J-Rapid Program of the Japan Science and Technology Agency (JST-PROJECT15657342). This study was also funded by JSPS KAKENHI (Grant Number 16H03149) and the Collaborative Centre of Research 28-1 of the Disaster Prevention Research Institute of Kyoto University. All landslide data used in this paper are freely available for download at the Japan Landslide Society $(\mathrm{h} \mathrm{t} \mathrm{t} \mathrm{p} \mathrm{s} \mathrm{:} \mathrm{/} \mathrm{/} \mathrm{j} \mathrm{a} \mathrm{pa} \mathrm{n.} 1$ a n d s l i d e soc.org/Reports/DisasterReports/Tsouetal2018/landslidedata.zip).

\section{REFERENCES}

Angster, S., Fielding, E. J., Wesnousky, S., Pierce, I., Chamlagain, D., Gautam, D., Upreti, B. N., Kumahara, Y., and Nakata, T., 2015, Field reconnaissance after the 25 April $2015 \mathrm{M}$ 7.8 Gorkha Earthquake. Seismological Research Letters, v. 86, pp. $1506-1513$.

British Geological Survey, 2015, Nepal Earthquake Response. http://www.bgs.ac.uk/research/earthHazards/epom/Nep alearthquakeresponse.html

Chiaro, G., Kiyota, T., Pokhrel, R. M., Goda, K., Katagiri, T., and Sharma, K., 2015, Reconnaissance report on geotechnical and structural damage caused by the 2015 Gorkha Earthquake, Nepal. Soils and Foundations, v. 55, pp. 1030-1043.

Chigira, M., 2014, Geological and geomorphological features of deep-seated catastrophic landslides in tectonically active regions of Asia and implications for hazard mapping. Episodes, v. 37, pp. 284-294.
Chigira, M., Wu, X. Y., Inokuchi, T., and Wang, G., 2010, Landslides induced by the 2008 Wenchuan earthquake, Sichuan, China. Geomorphology, v. 118, pp. 225-238.

Collins, B. D. and Jibson, R. W., 2015, Assessment of existing and potential landslide hazards resulting from the April 25, 2015 Gorkha, Nepal earthquake sequence. USGS Open File Report (ver. 1.1, August 2015).

Duputel, Z., Vergne, J., Rivera, L., Wittlinger, G., Farra, V., and Hetenyi, G., 2016, The 2015 Gorkha earthquake: A large event illuminating the Main Himalayan Thrust fault. Geophysical Research Letters, v. 43, pp. 2517-2525.

Harvey, J. E., Burbank, D. W., and Bookhagen, B., 2015, Alongstrike changes in Himalayan thrust geometry: Topographic and tectonic discontinuities in western Nepal. Lithosphere, v. 7, pp. 511-518.

Higaki, T., Hasegawa, O., Yagi, H., and Wakai, A., 2015, Emergency survey report on geo-hazards caused by the Gorkha Earthquake in Nepal. Journal of the Japan Landslide Society, v. 52, pp. 203-206 (in Japanese).

Kargel, J.S., Leonard, G.J., Shugar, D.H., Haritashya, U.K., Bevington, A., Fielding, E.J., Fujita, K., Geertsema, M., Miles, E.S., Steiner, J., Anderson, E., Bajracharya, S., Bawden, G.W., Breashears, D.F., Byers, A., Collins, B., Dhital, M.R., Donnellan, A., Evans, T.L., Geai, M.L., Glasscoe, M.T., Green, D., Gurung, D.R., Heijenk, R., Hilborn, A., Hudnut, K., Huyck, C., Immerzeel, W.W., Jiang, L., Jibson, R., Kääb, A., Khanal, N. R., Kirschbaum, D., Kraaijenbrink, P.D.A., Lamsal, D., Liu, S., Lv, Mingyang., McKinney, D., Nahirnick, N.K., Nan, Z., Ojha, S., Olsenholler, J., Painter, T. H., Pleasants, M., Pratima., K., Yuan, Q., Raup, B.H., Regmi, D., Rounce, D. R., Sakai, A., Shangguan, Donghui., Shea, J.M., Shrestha, A. B., Shukla, A., Stumm, D., van der Kooij, M., Voss, K., Wang, X., Weihs, B., Wolfe, D., Wu, L., Yao, X., Yoder, M.R., and Young, N., 2015, Geomorphic and geologic controls of geohazards induced by Nepal's 2015 Gorkha earthquake. Science, v. 351, aac8385, DOI: 10.1126/science.aac8353.

Keefer, D. K., 1984, Landslides caused by earthquakes. Geological Society of America Bulletin, v. 95, pp. 406-421.

Lin, C. W., Shieh, C. L., and Yuan, B. D., 2004, Impact of ChiChi earthquake on the occurrence of landslides and debris flows: example from the Chenyulan River watershed, Nantou, Taiwan. Eng. Geol., v. 71, pp. 49-61.

Martha, T. R., Roy, P., Mazumdar, R., Govindharaj, K. B., and Kumar, K.V., 2017, Spatial characteristics of landslides triggered by the $2015 \mathrm{Mw} 7.8$ (Gorkha) and $\mathrm{Mw} 7.3$ (Dolakha) earthquakes in Nepal. Landslides, v. 14, pp. 697-704.

Roback, K., Clark, M. K., West, A. J., Zekkos, D., Li, G., Gallen, S. F., Chamlagain, D., and Godt, J. F., 2017, The size, distribution, and mobility of landslides caused by the 2015 
Mw 7.8 Gorkha earthquake, Nepal. Geomorphology, https://doi.org/10.1016/j.geomorph.2017.01.030.

Sapkota, S. N., Bollinger, L., and Perrier, F., 2016, Fatality rates of the $\mathrm{Mw} \sim 8.2,1934$, Bihar-Nepal earthquake and comparison with the April 2015 Gorkha earthquake. Earth, Planets and Space, v. 68:40.

Sato, H.P., Hasegawa, H., Fujiwara, S., Tobita, M., Koarai, M., Une, H., and Iwahashi, J., 2007, Interpretation of landslide distribution triggered by the 2005 Northern Pakistan earthquake using SPOT 5 imagery. Landslides, v. 4, pp. 113-122.

Shrestha, D.B. and Shrestha, J.N., 1986, Geological Map of Central Nepal. Scale: 1:250000. Department of Mines and Geology, Kathmandu.

Tang, C., Westen, C. J.V., Tanya , H., and Jetten, V.G., 2016, Analysing post-earthquake şsindslide activity using multitemporal landslide inventories near the epicentral area of the 2008 Wenchuan earthquake. Nat Hazards Earth Syst Sci Discuss., v. 16, pp. 2641-2655.
Tiwari, B., Ajmera, B., and Dhital, S., 2017, Characteristics of moderate- to large-scale landslides triggered by the $\mathrm{Mw}$ 7.82015 Gorkha earthquake and its aftershocks. Landslides, Springer Nature, 14 (4), 1297-1318, DOI: 10.1007/s10346-016-0789-0.

Tsou, C.Y., Chigira, M., Higaki, D. Sato, G., Yagi, H., Sato, H. P., Wakai, A., Dangol, V., Amatya, S.C., and Yatagai, A., 2017, Topographic and geologic controls on landslides induced by the 2015 Gorkha earthquake and its aftershocks: an example from the Trishuli Valley, central Nepal, Landslides,https://doi.org/10.1007/s10346-017-0913-9.

USGS, 2015, Magnitude 7.8 earthquake in Nepal. https://www2.usgs.gov/blogs/features/usgs_top_story/m agnitude-7-8-earthquake-in-nepal/

Wakai, A. and Ugai, K., 2004, A simple constitutive model for the seismic analysis of slopes and its applications. Soils and Foundations, v. 44, pp. 83-97. 
